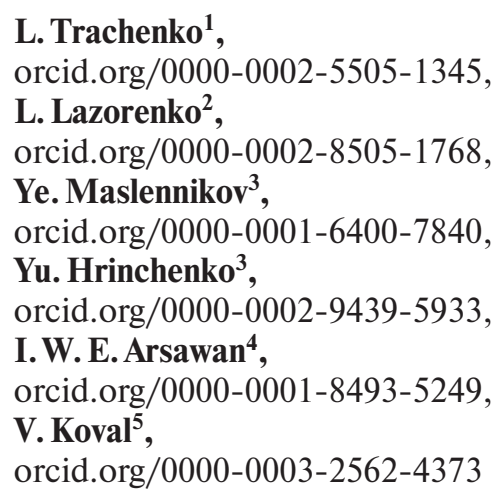

1 - Odesa National University of Economics, Odesa, Ukraine 2 - State University of Telecommunication, Kyiv, Ukraine 3 - Odesa National I. I. Mechnikov University, Odesa, Ukraine 4 - Politeknik Negeri Bali, Bali, Indonesia

5 - National Academy of Sciences of Ukraine, Kyiv, Ukraine, e-mail: victor-koval@ukr.net

\title{
OPTIMIZATION MODELING OF BUSINESS PROCESSES OF ENGINEERING SERVICE ENTERPRISES IN THE NATIONAL ECONOMY
}

Purpose. Construction of an economic and mathematical model of the optimal organization of a system of business processes and its testing at an enterprise in the field of engineering services.

Methodology. Methods of analysis and synthesis, systematization, theoretical generalization are used to study approaches to optimizing business processes of enterprises; modeling - to create an economic and mathematical model of the optimal organization of the system of business processes; approbation of the developed model at an enterprise in the field of engineering services.

Findings. The article proves the need to assess the impact of various economic factors on the financial results of economic activities of enterprises and the construction of business systems of enterprises, economic and mathematical models for their optimization. It has been determined that business process modeling is an effective means of improving quality management systems in accordance with the requirements of the international standard ISO 9001:2015, determining, identifying and minimizing the risks of enterprises, ensuring their successful activities in general. An economic and mathematical model has been developed for the optimal organization of the system of business processes of an enterprise as a means of maximizing the total profit from the implementation of works and services.

Originality. An economic and mathematical model of the optimal organization of the system of business processes of enterprises in the field of engineering services has been built as an effective tool for improving their quality management systems and activities in general.

Practical value. The use of the constructed economic and mathematical model of the optimal organization of the system of business processes of enterprises in the field of engineering services will provide the management team with important information for making management decisions aimed at improving quality management systems, achieving key business goals and maximizing profits.

Keywords: business process system, economic and mathematical model, profit maximization, engineering services, business process costs, quality management systems, ISO 9001:2015

Introduction. Due to the intensification of globalization processes in recent years, the negative impact of the global financial and economic crisis has spread to all sectors of the national economy, including engineering services. At the present stage of industrial development of Ukraine, this area is one of the priority industries, current activities, which significantly affects the formation of gross domestic product and economic growth in general. The urgent task today is to increase the economic performance of domestic enterprises in the field of engineering services to improve the economic development of the country.

Ukraine's desire for European and global economic cooperation requires domestic companies to innovate, more promising approaches to the formation of quality management systems (QMS) in the context of international standards, including ISO 9001:2015, their integration into business processes. At the current stage of development of domestic enterprises, in particular in the field of engineering services, it is necessary to pay close attention to the relationship and interdependence of costs in terms of quantity and quality of their business processes. It is indisputable to ensure effective business process management based on the evaluation and modeling of business systems by combining specific processes that can meet customer needs, defend their position in domestic and international markets and achieve key goals of the enterprise. One

(C) Trachenko L., Lazorenko L., Maslennikov Ye., Hrinchenko Yu., Arsawan I. W. E., Koval V., 2021 of the effective means of strengthening the company's position in the market and improving the economic performance of its activities is the optimization of the business process system.

This process is complex, in the context of international activities it is provided by different approaches and methods of their modeling, requires special tools and technologies, should provide a close link between the volume of work (services) and their efficiency, as well as affect the objects of management at all stages of their implementation. At the same time, the definition and application of approaches to optimization modeling of the business process system in the context of international activities is an effective tool for improving the activities of enterprises, forecasting and minimizing potential risks.

To achieve the objectives in the development of economic relations it is necessary to assess the impact of various economic factors on financial performance, justify the use of special technologies for building business systems of enterprises with the definition of specific processes needed to achieve enterprise goals, economic and mathematical models, their optimization, the use of special techniques, concepts that would allow managers to make rational decisions and predict the outcome of their implementation. Modern market conditions determine the growing role of the use and implementation of modern methods of modeling and optimization of business processes in enterprises.

Literature review. Analysis of recent research and publications. Theoretical and methodological aspects of business process optimization were studied by O. Korzachenko, V. Getman 
[1] (criteria for improving business processes and methods of their optimization), A. V. Babikova, M.N. Korsakov and A. D. Sarafanov [2] (methodologies based on process approach), M. Indulska, J. Recker, M. Rosemann and P. Green, [3] (approaches, tools, methods of business process modeling), N. I. Chukhrai, S. I. Matviy [4] (a model of forming the optimal cost structure for innovation processes is proposed), O. Chukurna, et al. [5] (development of economic and mathematical model of optimization of transaction costs of machine-building enterprises), D. L. Luong, D. H.Tran and P.T. Nguyen [6] (substantiated the need to use economicmathematical methods to solve economic problems in management), J. Vom Brocke and J. Mendling [7] (the main parameters of optimization of the production structure of diversified enterprises are determined), O. G. Melnyk, O.V. Mukan and M. L. Zlotnyk [8].

Effective cost management of enterprise innovation processes cannot be based solely on empirical approach or senior management experience. The management mechanism should be based on a certain economic and mathematical model that would reflect the essential relationships of resources used and the end results of innovation [4].

The authors have developed a new integrated approach to managing the costs of innovation processes. Its essence is to highlight the stages of the innovation process in the coordinate system of resource provision, which allowed building a dynamic model of innovation processes in the machine-building enterprise, where factors of efficiency and adaptability over time act as target functions. This approach can be applied with an emphasis on solving current problems on the amount of costs or time horizons.

A promising area in the field of business planning is the study on business processes and their optimization, because in modern business conditions, the company that has decided to optimize business processes can choose a methodology from several standards, use simple flowcharts or develop their own form of description [9]. The choice of methodologies should take into account not only their capabilities and shortcomings, but also the purpose of using the created business process models.

One of the ways to improve the management of transaction costs of machine-building enterprises is the principle of optimization, which involves identifying productive costs, the implementation of which has a positive impact on financial results, and unproductive costs, which, in turn, inhibit economic development and are a significant burden for domestic enterprises [5]. The main purpose of commercial activity of enterprises is to maximize profits from the sale of products, works and services. The cost of performing business processes of the enterprise is one of the main limiters of profit and at the same time the main factor that affects the volume of sales, performance of works, provision of services. In view of this, the process of minimizing the cost of business processes should be considered taking into account the issue of maximizing the company's profits [10].

To optimize the cost of business processes, various optimally criteria are chosen, including "maximum profit from sales" and "maximum income from sales".

Despite a large amount of research in this area, approaches to business process modeling as a means of effective management and improvement of economic activity of enterprises need refinement and development, so there is a need to develop economic and mathematical model of business process optimization and justify its use with certain restrictions.

Purpose. The purpose of the article is to build an economic and mathematical model of the optimal organization of the business process system and its testing at the enterprise in the field of engineering services.

Methods. The article uses methods of analysis and synthesis, systematization, theoretical generalization to study approaches to optimizing business processes of enterprises; modeling - to create an economic and mathematical model of the optimal organization of the business process system; ap- probation of the developed model at the enterprise in the field of engineering services.

Results. Effective business process management in the field of engineering services should be considered in the context of the application of modern approaches to quality management, with an emphasis on optimization modeling. The analysis of theoretical and practical materials of foreign and domestic scientists on the problems of ensuring the effective operation of enterprises in the field of engineering services shows that their solutions are often associated with the optimization and improvement of business processes. At the same time, optimization modeling of business processes can be an effective means of improving quality management systems in accordance with the requirements of the international standard ISO 9001:2015.

Successful activity of Ukrainian enterprises, their sustainable development, which includes economic, social and environmental aspects, is possible due to the improvement and optimization of business processes aimed at meeting the needs of consumers and other stakeholders, taking into account market conditions. When optimizing business processes, it is advisable to apply a systematic approach with the definition of a number of measures and management functions, such as planning, organization, control, improvement. Optimization modeling of business processes is an effective tool for improving the performance of enterprises and meeting the needs of their customers [1, 11].

In addition, the construction of an optimization model of business processes allows the company to establish mutually beneficial relationships with external organizations, suppliers, customers, to create favorable conditions for the fruitful work of the company's staff. It is indisputable that the optimization of business processes is a tool for determining, identifying and minimizing risks in quality management systems and enterprise operations in general [2].

When modeling business processes, it is very important to decide on the structure and content of modeling objects, to determine which elements a business process should consist of [3].

Business process optimization is one aspect of organizational development, in which a number of actions are taken by the process owner to identify, analyse and improve existing business processes in the enterprise in accordance with goals and objectives, such as increasing profits and productivity, reducing costs and more. Also, business process improvement (BPI) is a way to change existing business processes, which improves the quality of the product or service, in order to meet the needs of customers and consumers [12, 13].

An important indicator of economic activity of enterprises, in particular in the field of engineering services, is its income from the implementation of business processes (work performed and services). This indicator determines the purpose of entrepreneurial activity, as income depends on the company's profit, profitability and solvency. Analysis of the impact of business process costs on profits is a complex economic task that requires a detailed study on the relationship between profits from the sale of works, services and the types of costs for their implementation.

A number of enterprises in the field of energy engineering services are studied whose quality management systems are certified to meet the requirements of ISO 9001:2015. This is a guarantee of the proper quality of their business processes covered by certification: design; performance of works on manufacturing of electrical equipment; carrying out electrical work; adjustment works. The researched enterprises in the field of engineering services carry out a set of works for internal consumption and for external customers and could be involved in work projects in various combinations. For the optimal organization of the business process system, it is necessary to ensure the rational use of resources for their implementation and financial resources, to effectively use the available human resources at the facilities, to focus on planning work in time, taking into account the risks. 
It is necessary to form a list of projects, the implementation of which is possible within the available resources and will ensure the achievement of the maximum economic result of the enterprise.

We assume that within the system $m$ of business processes $i=\overline{1, m}$ it is possible to implement $n$ projects $j=\overline{1, n}$. We believe that each individual project can contain a set of all business processes or any combination thereof. In addition, each project $j$ is determined by the composition of costs in kind of resources of type $h(h=\overline{1, l})$, which are necessary for its implementation in the process $i$. It is worth noting that a single list of resources is used for processes and projects. Thus, during the analysis of $n$ projects, the cost of each process $i$ is advisable to be displayed in the form of a matrix $A_{i}$ of dimension $l \times n$

$$
A_{i}=\left(\begin{array}{cccc}
a_{11}^{i} & a_{12}^{i} & \ldots & a_{1 n}^{i} \\
\cdot & \cdot & \cdot & \cdot \\
a_{l 1}^{i} & a_{l 2}^{i} & \ldots & a_{\mathrm{ln}}^{i}
\end{array}\right) .
$$

The cost of the corresponding resource for all projects involving process $i$, characterizes each row $h$ of the matrix $A_{i}$. Column $j$ corresponds to the composition of project costs $j$ for all resources. In the case where the element of the cost matrix $A_{i}: a_{h j}^{i}=0$, we assume that the resource $h$ is not used by the project $j$.

The zero column of the matrix $A_{i}, k\left(a_{h k}^{i}=0, h=\overline{1, l}\right)$, corresponds to the situation when the process $i$ is completely removed from the project $k$.

To implement projects, the process system is provided with resources of magnitude $b_{h}=0, h=\overline{1, l}$. We assume that the total resource needs in the implementation of all $\mathrm{n}$ projects under study exceed their available volumes. In view of this, the urgent task is to form a list of projects that are possible within the available resources and will give the maximum economic result. In its content, this problem corresponds to the class of mathematical problems of choice [14] In economic and economic-mathematical literature, its various substantial and mathematical statements, for example works are resulted [15, 16]. The main distinguishing feature of this task is that the projects under study are not the same in composition, can contain any combination of $\mathrm{m}$ processes. Therefore, it is advisable to formulate an economic and mathematical setting of the problem of choice, taking into account the above feature and general ideas about the conditions of business processes.

It should be noted that the criterion for selecting projects (business process systems) is to maximize the total profit from their implementation $[15,16]$. However, in the mathematical record of this criterion it is important to reflect the probable risks of these projects. To assess the risks of project $j$, it is advisable to use the probability $r_{j}$ of its unsatisfactory completion [17]. These probabilities can be determined by an expert method, in particular, using an empirical scale of risks (Table 1).

The objective function of the optimization problem of project selection can be written as follows

Table 1

Empirical scale of acceptable level of risk

\begin{tabular}{|c|c|l|}
\hline No. & $\begin{array}{c}\text { Probability of undesirable outcome } \\
\text { (magnitude of risk) }\end{array}$ & Risk gradation \\
\hline 1 & $0.0-0.1$ & minimum \\
\hline 2 & $0.1-0.3$ & small \\
\hline 3 & $0.3-0.4$ & average \\
\hline 4 & $0.4-0.6$ & high \\
\hline 5 & $0.6-0.8$ & maximum \\
\hline 6 & $0.8-1.0$ & critical \\
\hline
\end{tabular}

$$
Z=\sum_{j=1}^{n}\left(1-r_{j}\right) P_{j} x_{j} \rightarrow \max ,
$$

where $P_{j}$ is profit from project implementation $j ; r_{j}$ is probability; $x_{j} \in\{0,1\}$ is Boolean variable, which becomes important $x_{j}=1$, if project $j$ is selected for implementation, and $x_{j}=0-$ otherwise.

Thus, function (2) is a weighted sum of project profit values, in which the weights are the probabilities of favorable results for their implementation $1-r_{i}$.

In order to form a mathematical setting of this problem of project selection, the maximized function (2) must be supplemented by a system of constraints that reflect the significant technical and economic conditions of project implementation

$$
\begin{gathered}
\sum_{i=1}^{m} \sum_{j=1}^{n} a_{h j}^{i} x_{j} \leq b_{h}, \quad h=\overline{1, l} ; \\
\sum_{i=1}^{m} \sum_{h=1}^{l} \sum_{j=1}^{n} c_{h} a_{h j}^{i} x_{j} \leq F ; \\
\sum_{h=1}^{l} \sum_{j=1}^{n} c_{h} a_{h j}^{i} x_{j} \leq F_{i}, \quad i=\overline{1, m} ; \\
\overline{\sum_{j=1}^{m} P_{j} x_{j}} \geq \underline{E} ; \\
\sum_{j=1}^{n} \sum_{j=1}^{n} \sum_{h=1}^{l} c_{h} a_{h j}^{i} x_{j} x_{j} \\
\sum_{j=1}^{n} \sum_{h=1}^{l} c_{h} a_{h j}^{i} x_{j} \\
\sum_{h=1}^{l} \sum_{j=1}^{n} c_{h} a_{h j}^{i} x_{j} \geq \underline{S}_{i}, \quad i=\overline{1, n} ; \\
x_{j} \in\{0,1\}, \quad j=\overline{1, m} ;
\end{gathered}
$$

where $c_{h}$ is the price of the resource of the species $h ; F$ is the total amount of funds available to the researched enterprise for the implementation of projects; $F_{i}$ is the amount of financial resources allocated for the implementation of the process $i ; \underline{E}$ is the lower limit of the efficiency of the whole set of processes; $\underline{E}_{i}$ is a similar value for the process $i ; p_{i j}$ is profit from project implementation $j$ at the stage of process $i$ (if the process $i$ is not used in the project $j$, then we consider $\left.p_{i j}=0\right): \sum_{i=1}^{m} p_{i j} \neq P_{j} ; \underline{S}_{i}$ is the value of the minimum allowable cost of work performed by the process $i$.

Conditions (3-9) have the following meaning:

- inequalities (3) are restrictions on the implementation of business processes, which are determined by the available resources of the enterprise;

- conditions $(4,5)$ reflect financial constraints for all processes in general and in terms of individual processes;

- inequalities $(6,7)$ set requirements for the economic efficiency of the implementation of processes;

- constraints (8) reflect the conditions for the minimum required load of individual processes;

- relations (9) determine the type of required variables.

Note that for a specific project selection task, conditions (4, 5 and 6,7$)$ can be written both jointly and separately. In this case, if financial constraints $(4,5)$ are applied simultaneously, then in this case equality $\sum_{i=1}^{m} F_{i}=F$ may not be executed. It is perfectly acceptable when $\sum_{i=1}^{m} F_{i}>F$ and the necessary financial 
balance in the optimal solution of the problem under consideration will be provided by the implementation of inequality (4).

Mathematical model (2-9) belongs to the class of problems of integer linear programming with Boolean variables, the methods for solving which are well known and implemented in many software products.

Thus, an economic-mathematical model of optimal organization of business processes is built, the use of which should increase the level of objectivity, validity and accuracy of management decisions. Approbation of the economic-mathematical model of the optimal organization of business processes was carried out at the enterprises of the sphere of engineering services. The article presents the results of its application at LLC "Chornomorenerhospetsmontazh". Types of resources for the implementation of each of the business processes of the studied enterprise are given in Table 2.

According to the developed model of the optimum organization of business processes, we carry out calculations on two directions of restrictions: the cost of implementing business processes; by the number of staff involved in business processes.
1. Limitations on the costs of implementing business processes. Profit from the implementation of business processes of the enterprise in the field of engineering services and the cost of resources for their implementation are given in Table 3 (implemented quality management system according to the international standard ISO 9001:2008). According to the business process optimization model, we perform calculations based on four business processes: $x_{1}-$ design of power supply facilities, $x_{2}-$ carrying out electrical work, $x_{3}$ - performance of works on manufacturing of electrical equipment, $x_{4}-\mathrm{ad}-$ justment works. Table 4 shows the data of calculations for the optimization of business processes with cost constraints for their implementation.

2. Restrictions on the number of staff involved in the implementation of business processes of the enterprise in the field of engineering services are given in Table 5. Calculations of the optimal system of business processes with a limit on the number of staff involved in their implementation are given in Table 6.

The obtained results of calculations indicate that the optimal arrangement of business processes with limited costs for

Table 2

Types of business processes of the enterprise in the field of engineering services and resources for their implementation

\begin{tabular}{|c|c|c|c|c|c|c|c|c|c|c|c|c|c|c|c|}
\hline \multirow[b]{2}{*}{ Types of business processes } & \multicolumn{15}{|c|}{ Types of resources } \\
\hline & 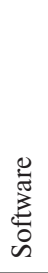 & 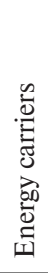 & 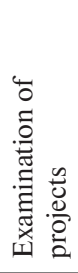 & 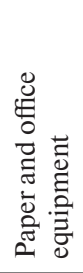 & $\begin{array}{l}\bar{\Xi} \\
\Xi \\
0 \\
0 \\
0 \\
0\end{array}$ & $\frac{\vec{E}}{\vec{J}}$ & $\begin{array}{l}\overrightarrow{0} \\
0 \\
\dot{0} \\
\vdots \\
0 \\
0\end{array}$ & 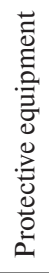 & 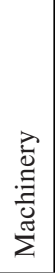 & 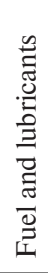 & 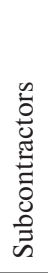 & 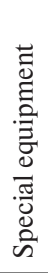 & 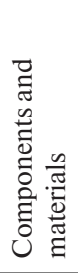 & 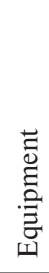 & 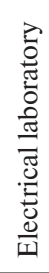 \\
\hline Design of power supply facilities & $\mathrm{x}$ & $\mathrm{x}$ & $\mathrm{x}$ & $\mathrm{x}$ & $\mathrm{x}$ & $\mathrm{x}$ & & & & & & & & & \\
\hline Carrying out electrical work & & $\mathrm{x}$ & & & $\mathrm{x}$ & $\mathrm{x}$ & $\mathrm{x}$ & $\mathrm{x}$ & $\mathrm{x}$ & $\mathrm{x}$ & $\mathrm{x}$ & $\mathrm{x}$ & $\mathrm{x}$ & $\mathrm{x}$ & \\
\hline $\begin{array}{l}\text { Performance of works on manufacturing of electrical } \\
\text { equipment }\end{array}$ & & $\mathrm{x}$ & & & $\mathrm{x}$ & $\mathrm{x}$ & $\mathrm{x}$ & $\mathrm{x}$ & & & & & $\mathrm{x}$ & $\mathrm{x}$ & \\
\hline Adjustment works & & $\mathrm{x}$ & & & $\mathrm{x}$ & $\mathrm{x}$ & $\mathrm{x}$ & $\mathrm{x}$ & & $\mathrm{x}$ & & & & & $\mathrm{x}$ \\
\hline
\end{tabular}

Table 3

Optimal system of business processes with restrictions on the costs of their implementation (implemented quality management system according to ISO 9001:2008)

\begin{tabular}{|l|c|c|c|c|c|}
\hline & $x_{1}$ & $x_{2}$ & $x_{3}$ & $x_{4}$ & Total \\
\hline Profit from the implementation of business processes $P_{j}$, thousand UAH & 2824.2 & 70345.8 & 7444.44 & 6056.64 & 86671.08 \\
\hline Resource costs for business processes $a_{h k}^{i}$ thousand UAH & 2615.0 & 65135.0 & 6893.0 & 5608.0 & 80251.0 \\
\hline The total amount of funds $F$, thousand UAH & 11177 & & & & \\
\hline
\end{tabular}

Note: $x_{1}$ - designing of power supply facilities, $x_{2}$ - carrying out electrical work, $x_{3}$ - performance of works on manufacturing of electrical equipment, $x_{4}$ - adjustment works

Table 4

Calculations of the optimal system of business processes with a limit on the cost of their implementation of the enterprise in the field of engineering services

\begin{tabular}{|c|c|c|c|c|}
\hline Types of business processes & $\begin{array}{l}\text { Expenses for } \\
\text { business processes, } \\
\text { thousand UAH }\end{array}$ & $\begin{array}{l}\text { Optimal organization } \\
\text { of the business } \\
\text { process system }\end{array}$ & $\begin{array}{l}\text { The cost of implementing the } \\
\text { optimal system of business } \\
\text { processes, thousand UAH }\end{array}$ & $\begin{array}{l}\text { The total amount } \\
\text { of funds, } F, \\
\text { thousand UAH }\end{array}$ \\
\hline Design of power supply facilities $\left(x_{1}\right)$ & 2824.2 & 1 & \multirow{4}{*}{10268.64} & \multirow{4}{*}{11177.0} \\
\hline Carrying out electrical work $\left(x_{2}\right)$ & 70345.8 & 0 & & \\
\hline $\begin{array}{l}\text { Performance of works on manufacturing of } \\
\text { electrical equipment }\left(x_{3}\right)\end{array}$ & 7444.44 & 1 & & \\
\hline Adjustment works $\left(x_{4}\right)$ & 6056.64 & 0 & & \\
\hline
\end{tabular}

Note: 1 - is part of the optimal system of business processes; 0 - not included in the optimal system of business processes 
their implementation is: design and execution of works for the manufacture of electrical equipment (costs amount to 10268.64 thousand UAH).

The results of calculations of the optimal system of business processes with a limit on the number of staff are as follows: 39 people must be involved to perform them.

For comparison, research and calculations were conducted to optimize the business process system of the enterprise in the field of engineering services for 2018, when the transition of its quality management systems to the version of the international standard ISO 9001:2015 took place (Table 7).

The calculations were performed in a similar way using Excel using data analysis and finding solutions (Table 8). As a result of application of the model, the optimal combination of business processes of the enterprise with restrictions on the costs of their implementation was performed as follows: de-

Table 5

Optimal system of business processes with a limit on the number of staff involved in their implementation (implemented quality management system according to ISO 9001:2008)

\begin{tabular}{|l|c|c|c|c|c|}
\hline & $x_{1}$ & $x_{2}$ & $x_{3}$ & $x_{4}$ & Total \\
\hline Profit from the implementation of business processes $P_{j}$, thousand UAH & 2824.2 & 70345.8 & 7444.44 & 6056.64 & 86671.08 \\
\hline The number of staff to perform business processes $a_{h k}^{i}$, persons & 25 & 81 & 14 & 17 & 137 \\
\hline The total amount of funds $F$, thousand UAH & 11177 & & & & \\
\hline
\end{tabular}

Note: $x_{1}$ - designing of power supply facilities, $x_{2}$ - carrying out electrical work, $x_{3}$ - performance of works on manufacturing of electrical equipment, $x_{4}$ - adjustment works

Table 6

Calculations of the optimal system of business processes with a limit on the number of personnel of the enterprise

\begin{tabular}{|c|c|c|c|c|}
\hline Types of business processes & $\begin{array}{l}\text { Expenses for } \\
\text { business processes, } \\
\text { thousand UAH }\end{array}$ & $\begin{array}{l}\text { Optimal organization } \\
\text { of the business } \\
\text { process system }\end{array}$ & $\begin{array}{l}\text { The number of staff involved } \\
\text { in the implementation of the } \\
\text { business processes, persons }\end{array}$ & $\begin{array}{l}\text { Number of staff to } \\
\text { perform business } \\
\text { processes, persons }\end{array}$ \\
\hline Design of power supply facilities $\left(x_{1}\right)$ & 2824.2 & 1 & \multirow[t]{4}{*}{39} & \multirow[t]{4}{*}{137} \\
\hline Carrying out electrical work $\left(x_{2}\right)$ & 70345.8 & 0 & & \\
\hline $\begin{array}{l}\text { Performance of works on manufacturing of } \\
\text { electrical equipment }\left(x_{2}\right)\end{array}$ & 7444.44 & 1 & & \\
\hline Adjustment works $\left(x_{4}\right)$ & 6056.64 & 0 & & \\
\hline
\end{tabular}

Note: 1 - is part of the optimal system of business processes; 0 - not included in the optimal system of business

Table 7

The optimal system of business processes of the engineering service enterprise with a limit on the cost of their implementation and the number of staff involved in their implementation

\begin{tabular}{|l|c|c|c|c|c|}
\hline & $x_{1}$ & $x_{2}$ & $x_{3}$ & $x_{4}$ & Total \\
\hline Profit from the implementation of business processes $P_{j}$ & 4125.2 & 126283.1 & 10845.4 & 8246.1 & 149499.9 \\
\hline Resource costs for business processes $a_{h k}^{i}$, thousand UAH & 3200.1 & 92146.1 & 8543.2 & 6452.2 & 110341.7 \\
\hline The number of staff to perform business processes $a_{h k}^{i}$, persons & 25 & 81 & 14 & 17 & 137 \\
\hline The total amount of funds $F$, thousand UAH & 39158.2 & & & & \\
\hline
\end{tabular}

Note: $x_{1}$ - designing of power supply facilities, $x_{2}$ - carrying out electrical work, $x_{3}$ - performance of works on manufacturing of electrical equipment, $x_{4}$ - adjustment works

Table 8

Calculations of the cost and number of personnel of the engineering service enterprise (after the transition of the quality management system to the version of ISO 9001:2015)

\begin{tabular}{|c|c|c|c|c|}
\hline Types of business processes & $\begin{array}{l}\text { Expenses for } \\
\text { business processes, } \\
\text { thousand UAH }\end{array}$ & $\begin{array}{l}\text { Optimal organization } \\
\text { of the business } \\
\text { process system }\end{array}$ & $\begin{array}{l}\text { The cost of implementing } \\
\text { the optimal system of } \\
\text { business processes, } \\
\text { thousand UAH }\end{array}$ & $\begin{array}{l}\text { The number of staff involved } \\
\text { in the implementation of the } \\
\text { optimal system of business } \\
\text { processes, persons }\end{array}$ \\
\hline Design of power supply facilities $\left(x_{1}\right)$ & 3200.1 & 1 & \multirow[t]{4}{*}{18195.6} & \multirow[t]{4}{*}{56} \\
\hline Carrying out electrical work $\left(x_{2}\right)$ & 92146.1 & 0 & & \\
\hline $\begin{array}{l}\text { Performance of works on manufacturing } \\
\text { of electrical equipment }\left(x_{3}\right)\end{array}$ & 8543.2 & 1 & & \\
\hline Adjustment works $\left(x_{4}\right)$ & 6452.2 & 1 & & \\
\hline
\end{tabular}

Note: 1 - is part of the optimal system of business processes; $0-$ not included in the optimal system of business 
sign; performance of works on the manufacture of electrical equipment and commissioning (costs amount to 18195.625 thousand UAH). It is determined that in order to implement the optimal system of business processes it is necessary to involve 56 staff members. It is advisable to focus on important aspects of the indicators of economic activity of enterprises in the field of engineering services.

Profit from electrical work and resource costs for its implementation are 70345.8 thousand UAH and 65135.0 thousand UAH, respectively. It is obvious that the profit from electrical work and the cost of resources for their implementation is significantly higher than for design, implementation of works for the manufacture of electrical equipment and commissioning. However, given that the indicators of economic activity of the enterprise today are significantly influenced by macroeconomic factors, including political, economic ones (related to hostilities in eastern Ukraine and the annexation of Crimea), it is very difficult to obtain actual data for each business process. The calculation of profit from the implementation of business processes and costs were carried out on the number of contracts concluded in 2013 for their implementation, but the company received a net financial result - profit for this period is much lower than planned. The reason for this situation is the inability to fully comply with the terms of contracts and non-receipt of funds for work already performed. However, even in this situation, the proposed model allows companies in the field of engineering services to ensure effective management decisions to optimize business processes.

Conclusions. The analysis of business processes of the engineering service enterprises has allowed revealing the basic kinds of resources for designing, performance of works on manufacturing of the electrotechnical equipment, carrying out of electric installation works. The application of the developed economic-mathematical model allowed carrying out the optimal combination of design with works on the manufacture of electrical equipment and determining the number of staff required for involvement in business processes (costs amount to 18195.6 thousand UAH). It is determined that in order to implement an optimized system of business processes it is necessary to involve 56 staff members. This is essential information for senior management to make management decisions aimed at improving quality management systems, the quality of business processes and the enterprise as a whole.

\section{References.}

1. Korzachenko, O., \& Getman, V. (2011). Modelling the Choice of Optimal Structural Business Process Model in a Telecommunications Company. Computer Sciences, 45, 36-42. https://doi.org/10.2478/ v10143-011-0039-9.

2. Babikova, A. V., Korsakov, M. N., \& Sarafanov, A. D. (2017). Optimization of business processes of an industrial enterprise through the introduction of a process approach. Kreativnaya ekonomika, 11, 11951208. https://doi.org/10.18334/ce.11.11.38474.

3. Indulska, M., Recker, J., Rosemann, M., \& Green, P. (2009). Business process modeling: Current issues and future challenges. In International Conference on Advanced Information Systems Engineering, (pp. 501-514). Berlin: Springer. https://doi.org/10.1007/978-3642-02144-2 39

4. Chukhrai, N. I., \& Matviy, S. I. (2015). Business process reengineering in the centralization of the industrial enterprises management. Marketing and Management of Innovations, (3), 172-181.

5. Chukurna, O., Nitsenko, V., Kralia, V., Sahachko, Y., Morkunas, M., \& Volkov, A. (2019). Modelling and managing the effect of transferring the dynamics of exchange rates on prices of machinebuilding enterprises in Ukraine. Polish Journal of Management Studies, 19. https://doi.org/10.17512/pjms.2019.19.1.09.

6. Luong, D. L., Tran, D. H., \& Nguyen, P.T. (2021). Optimizing multi-mode time-cost-quality trade-off of construction project using opposition multiple objective difference evolution. International Journal of Construction Management, 21(3), 271-283. https://doi.org/10.10 $\underline{80 / 15623599.2018 .1526630 .}$
7. Vom Brocke, J., \& Mendling, J. (2018). Business process management cases. Digital Innovation and Business Transformation in Practice. Springer. https://doi.org/10.1007/978-3-662-63047-1.

8. Melnyk, O. H., Mukan, O. V., \& Zlotnik, M. L. (2019). Features of business processes modeling and its optimization in the context of international activities. Management and Entrepreneurship in Ukraine, 1(2), 43-52. https://doi.org/10.23939/smeu2019.02.043.

9. Mekonnen, N. (2019). Implementing business process reengineering (BPR) in government organization. International Journal of Advanced Research, (7), 109-120. https://doi.org/10.21474/ IJAR01/9482.

10. Inghels, D. (2020). Introduction to Modeling Sustainable Development in Business Processes: Theory and Case Studies. Springer Nature. https://doi.org/10.1007/978-3-030-58422-1.

11. Pérez-Álvarez, J.M., Maté, A., Gómez-López, M.T., \& Trujillo, J. (2018). Tactical Business-Process-Decision Support based on KPIs Monitoring and Validation. Computers in Industry, 102, 23-39. https://doi.org/10.1016/i.compind.2018.08.001.

12. Kotenko, S., Nitsenko, V., Hanzhurenko, I., \& Havrysh, V. (2020). The Mathematical Modeling Stages of Combining the Carriage of Goods for Indefinite, Fuzzy and Stochastic Parameters. International Journal of Integrated Engineering, 12(7), 173-180. https://doi. org/10.30880/ijie.2020.12.07.019.

13. Trachenko, L., Verkhoglyadova, N., Shevchenko, N., Kononova, I., \& Sokolovska, I. (2020) Assessment of quality management systems of service companies. Intellectual economics, 14(1), 45-66. https://doi.org/10.13165/IE-20-14-1-03.

14. Baiyere, A., Salmela, H., \& Tapanainen, T. (2020). Digital transformation and the new logics of business process management. European Journal of Information Systems, 29(3), 238-259. https://doi.org/1 0.1080/0960085x.2020.1718007.

15. Hutsaliuk, O., Koval, V., Tsimoshynska, O., Koval, M., \& Skyba, H. (2020). Risk Management of Forming Enterprises Integration Corporate Strategy. TEM Journal, 9(4), 1514-1523. https://doi. org/10.18421/TEM94-26.

16. Arsawan, I.W.E., Koval, V., Rajiani, I., Rustiarini, N.W., Supartha, W. G., \& Suryantini, N. P. S. (2020). Leveraging knowledge sharing and innovation culture into SMEs sustainable competitive advantage. International Journal of Productivity and Performance Management [Unpublished manuscript]. https://doi.org/10.1108/IJPPM-04-2020-0192. 17. Meidan, A., García-García, J.A., Escalona, M.J., \& Ramos, I. (2017). A survey on business processes management suites. Computer Standards \& Interfaces, 51, 71-86. https://doi.org/10.1016/j. csi.2016.06.003.

\section{Оптимізаційне моделювання бізнес-} процесів підприємств інжинірингових послуг у національній економіці

\section{Л. А. Траченко ${ }^{1}$, Л. В. Лазоренко ${ }^{2}$, С. І. Масленніков ${ }^{3}$, Ю.Л. Грінченко ${ }^{3}$, А. В. Е.Арсаван ${ }^{4}$, В. В. Коваль}

1 - Одеський національний економічний університет, м. Одеса, Україна

2 - Державний університет телекомунікацій, м. Київ, Україна

3 - Одеський національний університет імені І.І. Мечникова, м. Одеса, Україна

4 - Балійська державна політехніка, Балі, Індонезія 5 - Національна академія наук України, м. Київ, Україна, e-mail: victor-koval@ukr.net

Мета. Побудова економіко-математичної моделі оптимальної організації системи бізнес-процесів і апробація на підприємстві сфери інжинірингових послуг.

Методика. Методи аналізу й синтезу, систематизації, теоретичного узагальнення використані для дослідження підходів до оптимізації бізнес-процесів підприємств; моделювання - для створення економіко-математичної моделі оптимальної організації системи бізнес-процесів; апробація розробленої моделі на підприємстві сфери інжинірингових послуг. 
Результати. У роботі доведена необхідність оцінки впливу різних економічних факторів на фінансові результати господарської діяльності підприємств і побудови бізнес-систем підприємств, економіко-математичних моделей їх оптимізації. Визначено, що моделювання бізнес-процесів є ефективним засобом поліпшення систем управління якістю згідно з вимогами міжнародного стандарту ISO 9001:2015, визначення, ідентифікації та мінімізації ризиків підприємств, забезпечення їх успішної діяльності загалом. Розроблена економіко-математична модель оптимальної організації системи бізнес-процесів підприємства як засобу максимізації сумарного прибутку від реалізації робіт і послуг.

Наукова новизна. Побудована економіко-математична модель оптимальної організації системи бізнес-процесів підприємств сфери інжинірингових послуг як діє- вий інструментарій покращення їхніх систем управління якістю та діяльності загалом.

Практична значимість. Застосування побудованої економіко-математичної моделі оптимальної організації системи бізнес-процесів підприємств сфери інжинірингових послуг дозволить керівництву одержувати важливу інформацію для ухвалення управлінських рішень, спрямованих на покращення систем управління якістю, досягнення ключових цілей бізнесу й максимізацію прибутку.

Ключові слова: система бізнес-процесів, економіко-математична модель, максимізація прибутку, інжинірингові послуги, системи управління якістю, ISO 9001:2015

Recommended for publication by O. H. Yankovyi, Doctor of Economic Sciences. The manuscript was submitted 17.03.21. 